\title{
Participatory Multi-Criteria Analysis Methods: Comprehensive, Inclusive, Transparent and User-Friendly? An Application to the Case of the London Gateway Port
}

\begin{abstract}
The topic of how major transport projects should be assessed continues to generate disputes amongst academics, infrastructure specialists, investors and governments alike. Over the past decades, an increasing number of scholars have started to regard participatory multi-criteria analysis (MCA) as an approach capable of producing more comprehensive, transparent and democratic assessments than traditional appraisal techniques. However, whereas a number of participatory MCA methods have been devised, the large majority of them seem to have enjoyed limited practical application and there are very few studies examining their effectiveness. In order to assess the presumed benefits and the potential drawbacks of such methods, this paper considers the case of the London Gateway Port and compares the actual planning and decisionmaking process of this port development programme with the results of a multi-actor multi-criteria appraisal exercise, involving several project stakeholders and experts. As a result of this analysis, the paper contends that the contribution that participatory MCA procedures can potentially provide to the improvement of decision-making for large-scale transport infrastructure seems limited at best.
\end{abstract}

Keywords: Transport Projects; Appraisal; Evaluation; Decision-Making; Participatory Processes; Multi-Criteria Analysis; Participatory Multi-Criteria Analysis; London Gateway Port.

\section{Introduction}

At present major transport projects such as highways, high-speed railway lines, international airports and major container ports dominate development agenda worldwide. Projections concerning future investments are often hyperbolic. According to the estimates of the Organization for Economic Co-operation and Development (OECD, 2011), the global demand for transport projects could amount to over $\$ 8$ trillion between 2010 and 2030. In the UK, in particular, the government has committed to spend more than $£ 60$ billion ( $\$ 76$ billion) on transport infrastructure over the period 2015-2021. This will come alongside considerable investments by the private sector operators of the UK ports and airports (DfT, 2017).

However, decisions on large-scale transport projects are particularly contentious. Indeed, large-scale transport investments frequently imply multiple economic, environmental, social and political impacts, which go far beyond the physical assets that are being delivered (Dimitriou et al., 2011). Moreover, these impacts and consequences are not always positive and often results in uneven distributions of the gains and losses over space and time, and hence amongst population groups (Dean, 2018). Unsuccessful mega project developments, unable to meet the original expectations and entailing cost overruns, construction delays and various technical problems, benefit shortfalls and severe social, health and environmental consequences have been extensively documented in the international literature (see, amongst others, Hall, 1980; Morris and Hough, 1987; Flyvbjerg et al., 2003; Samset, 2012).

It is frequently contended (Dimitriou, 2009; Dimitriou et al., 2010, 2011 and 2016; Schutte, 2010; Barfod, 2012; Jensen, 2012; Leleur, 2012; Macharis and Nijkamp, 2013) that one of the 
main causes for these poor performances can be attributed to rather inadequate ex ante appraisal methodologies, negatively contributing to channel decisions into narrow frames of thought. In this regard, a number of scholars have expressed concern about the excessive importance given to economic-centric tools such as cost-benefit analysis (CBA) (Dimitriou et al., 2010 and 2016; Barfod and Salling, 2015; Barfod, 2018; Cornet et al., 2018a; Hickman and Dean, 2018; Salling et al., 2018; Hickman, 2019) and the exclusion of many project stakeholders and local community groups from the decision-making process (Macharis et al., 2012; Dimitriou et al., 2011; Macharis and Bernardini, 2015; Ward et al., 2016; Cornet et al., 2018b; Macharis and Baudry, 2018). In their papers, many of these authors have emphasized the need for employing participatory multi-criteria analysis (MCA) methods in the effort to produce more comprehensive assessments of project proposals, increase the participatory character of evaluations and improve the transparency of the appraisal and decision-making process. Over the past few decades, such methods have thus experienced a dynamic evolution, with new variants being devised and proposed at a face pace. A recent review of the relevant literature undertaken by Macharis and Bernardini (2015) indicates that, between 1985 and 2012, almost 300 journal articles focusing on the use of MCA and participatory MCA in transport appraisal have been published.

However, whereas the presumed benefits of participatory MCA methods, in terms of comprehensiveness of the analysis, transparency and democracy of the process, are widely espoused by their proponents, issues and problems potentially hampering their applicability and effectiveness do not seem to have been examined systematically (Dean et al., 2019). It is also not clear whether many of the proposed participatory MCA methods have enjoyed real-world applications or constitute mere academic proposals (Annema et al., 2015). Furthermore, when the methods have been really applied to 'live' practice, both the manner and the extent to which the results of the multi-actor multi-criteria appraisal exercises have been used to arrive at the final decision are not always distinctly explained by their proponents (Dean, 2018).

In order to assess the presumed benefits of such methods and examine in detail their possible drawbacks, this paper considers the case of the London Gateway Port, namely a new port complex, consisting of a container terminal, a logistics park and a port rail terminal, which is currently under construction at the edge of the Thames Estuary. Differently from several other large-scale transport projects which are being developed in the London Region, so far the London Gateway Port has remained largely unexplored by academics and has not been covered extensively by the media. The paper compares the actual planning and decision-making process of this port development programme, with the results of a multi-actor multi-criteria appraisal exercise, involving several project stakeholders and experts and undertaken according to the recommendations made by proponents of participatory MCA methods.

The rest of this paper consists of seven sections. Section 2 offers a description of the London Gateway Port and its planning and decision-making process. This section draws on several sources, including journal articles, online newspapers and reports, and interviews with experts and project stakeholders. Section 3 provides a brief overview of MCA and participatory MCA techniques, whilst Section 4 illustrates the key features of the specific approach to participatory MCA which was adopted in the case study. Section 5 concerns the specific application of this method to London Gateway Port. The results of the multi-actor multi-criteria appraisal exercise are presented in Section 6 . Section 7 critically discusses these outcomes. Finally, Section 8 concludes the paper by summarizing the main findings and key lessons learned from this exercise. 


\section{The London Gateway Port}

The London Gateway Port, whose construction started in February 2010, represents the first entirely new port to be built in Europe in the last 25 years (PortVision, 2013). The new port is located in Thurrock (Essex), about 48 kilometers east of central London, at the site of a former oil refinery. As illustrated in Figure 1, it also lies within the Thames Gateway Region, namely an area which has been designated by the UK Government as a national priority for urban regeneration (DCLG, 2007a and 2007b).

Figure 1 - The Thames Gateway Area and the London Gateway Port.

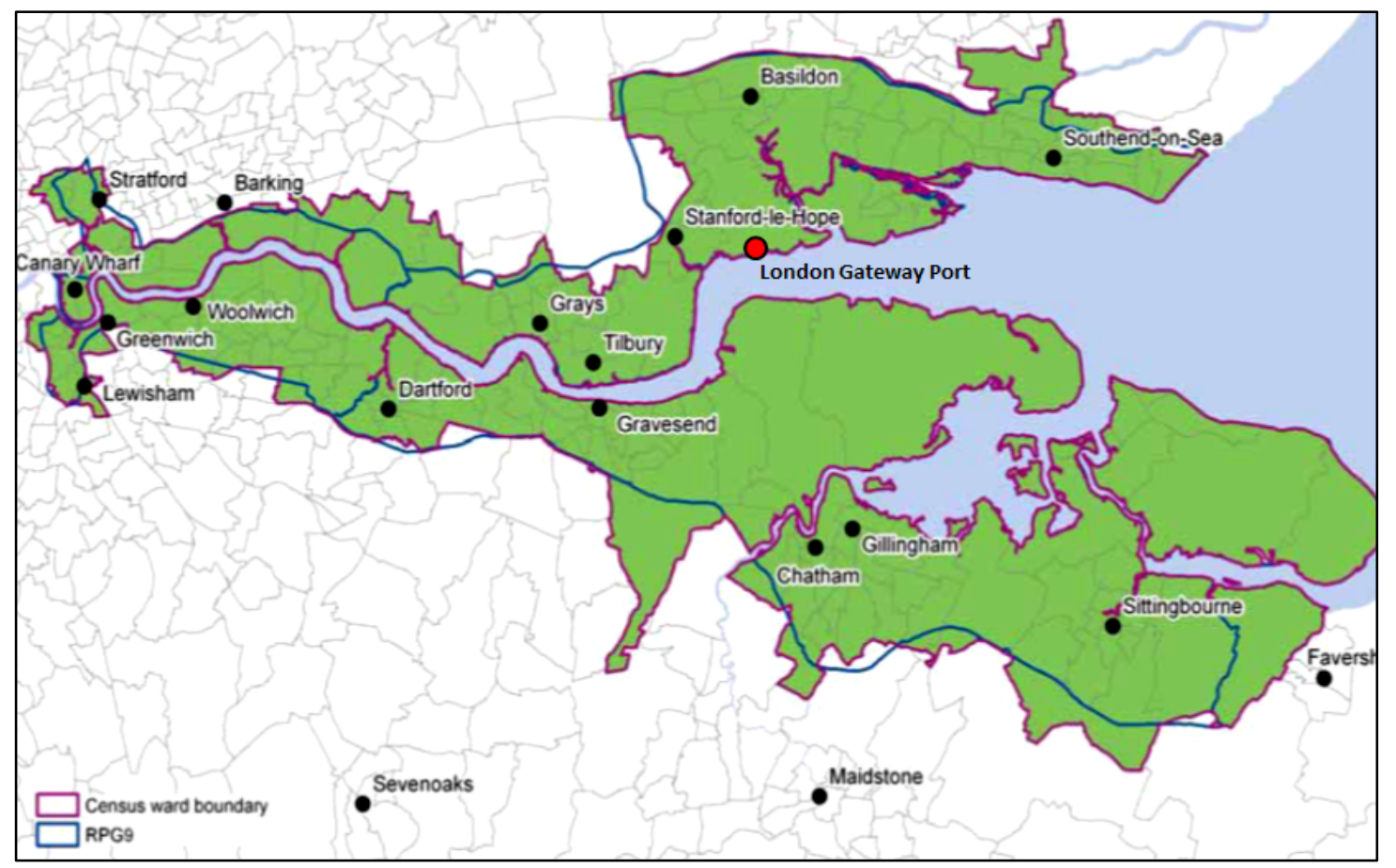

Source: (Adapted from) DCLG (2006b).

As explained in the previous section, the port complex consists of a new deep-sea, highly automated container terminal with six berths - three of which are already fully operational displayed along 2,700 meters of quay; a logistics park for the management of goods which, with an size of 83-hectare, constitutes the largest logistics centre in Europe; and the UK's longest port rail terminal, as a large share of containers are expected to travel to and from the port by rail (PLA, 2014, 2015 and 2016). The port development programme also encompasses the upgrade of some major road and rail links in the Thurrock area, and some dredging works in the Thames so as to enable even the largest containerships to call on the port (PLA, 2014). Total costs are estimated at $£ 1.5$ billion (about $\$ 2$ billion) (DCLG, 2007a and 2007b). The port complex, which, when fully developed, will provide an annual capacity of approximately 3.5 million TEUs (the international standard measure of containers based upon the volume of a standard twenty-foot long metal shipping container), is privately owned and operated by Dubai Port (DP) World, one of the largest marine terminal operators in the world.

The proposal for London Gateway Port was initially put forward in 2002 by the Peninsular and Oriental Steam Navigation Company (P\&O), an important British shipping and logistics company. In those years, the booming import trade to Britain, particularly from Asia, and the consequent 
general optimism about future container traffic, pervading both government and experts (DTLR, 2001; Asteris and Collins, 2007), led several UK port and terminal operators to promote major expansion programmes, often in strong competition with one another, in order to enhance their total container handling capacity (Wilmsmeier and Monios, 2013). The marketing position of P\&O was that, being relatively close to London, the London Gateway Port would be able to serve the UK capital better than the other major UK container ports such as Felixstowe and Southampton (Monios, 2017), thus potentially taking hundreds of trucks (coming from these ports and directed towards the London region) off Britain's roads.

A public inquiry into the need for the port complex and its potential impacts was held between February and September 2003 (Dean, 2018). The inquiry, conducted by an independent Planning Inspector reporting to central government, saw the participation of a number of stakeholder groups. The involved parties included: the Thurrock and Essex County Councils; English Nature (the current Natural England) and the Environmental Agency; local groups such as Shell Haven Project Environmental Action Committee (SPEAC); the Strategic Rail Authority, the Highways Agency and the Port of London Authority; the National Farmers Union; the Royal Society for the Protection of Birds (RSPB); and the owner of the rival Port of Felixstowe, that is Hutchison Port Holdings (DfT, 2003a and 2003b). Several regional and local bodies involved in the regeneration of the Thames Gateway Region, such as the East of England Development Agency and the Thurrock Urban Development Corporation, played a relatively minimal role in the public inquiry, whilst others such as the Greater London Authority and the London Development Agency chose even not to be involved in the public inquiry process. Many of these agencies and groups, however, continued exerting (directly or indirectly) their influence over the outcomes of the planning process, outside the public inquiry arena (Dean, 2018).

During the inquiry, P\&O presented its evidence regarding future container traffic growth and the consequent need for additional port capacity in the UK for at least 3.3 million TEUs a year (DfT, 2003b, sect. 4). The London Gateway Port, with an annual capacity of approximately 3.5 million TEUs, was thus presented as a project capable of meeting this future demand. These forecasts were, however, highly criticized especially by SPEAC and by Hutchison Port Holdings, although on two opposite grounds. Whereas the local action committee considered these estimates too optimistic, the rival port operator argued that the London Gateway alone could not solve the future UK container port capacity shortfall (DfT, 2003ab, sect. 4).

P\&O sought also to emphasize the clear alignment between the London Gateway Port and the overarching national policy objective of promoting economic development and regeneration in the Thames Gateway Region (DfT, 2003b, sect. 3). The project promoters claimed that, over a period of about 15 years, this new development initiative, besides of a significant number of construction jobs, would create about 14,500 direct jobs and support approximately 6,900 induced and indirect jobs in the surrounding regions (DfT, 2003b, sect. 5). However, these figures were considered unrealistic by SPEAC, given the highly automated nature of both the container port and the logistics parks (Neale, 2007). This local action committee also contended that the construction of a new large-scale port complex would almost certainly result in the closure of other smaller port and logistics facilities across Thurrock, thus leading to loss or transfer of jobs rather than creation of new employment opportunities (DfT, 2003b, sect. 5). Some concerns were also expressed by the Thurrock and Essex County Councils, whose main interest was to make sure that benefits resulting from the new port would accrue to residents of their authority's area (DfT, 2003b, sect. 5).

The status of the road and rail transport links to the port was discussed in considerable detail at the public inquiry. Thurrock Council, Essex County Council, the Highways Agency and the local community groups were quite critical over the possible adverse impacts of the new port on the 
local and strategic road network. Road enhancements and mitigation measures proposed by P\&O were not considered sufficient by these parties to accommodate the future traffic generated by the new port complex (DfT, 2003b, sect. 6a). The Strategic Rail Authority, by comparison, sought to ensure that adequate provision of rail infrastructure would be made to guarantee an approximate $25-30 \%$ rail mode share of inland freight transport, namely a target in line with those achieved by the ports of Southampton and Felixstowe (DfT, 2003b, sect. 6b).

Environmental concerns also featured prominently at a public inquiry. According to SPEAC, the proposal, which, when fully operational, would be likely to add approximately 50,000 vehicles a day to the road network, would increase dramatically air pollution levels (DfT, 2003b, sect. 7). English Nature also objected to the proposed development on account of its potential adverse effects on several valuable areas designated as protected sites under the EU Habitats and Birds Directives (DfT, 2003b, sects. 10 and 11). Other discussions concerned noise impacts, and the possible negative consequences of the port for the marine environment and the fishing industry in the Thames Estuary (DfT, 2003a and 2003b).

The enquiry officially closed in early September 2003 and the Inspector reported to central government in 2004. The Inspector largely accepted the evidence provided by the promoters (in terms of demand for the additional container handling capacity, scale of development and economic opportunities generated by the London Gateway Port) but recommended mitigation and compensation measures to minimize the adverse impacts of the development. The Secretary of State for Transport ultimately shared the Inspector's view and in July 2005 approved the scheme subject to a number of prerequisites being met. Key elements of the agreement included (DfT, 2003a, sect. 15): investments for tens of millions of pounds to enhance the road and highway network of the area (Coxon, 2007); the provision of two habitat compensation sites; and the implementation of an integrated environmental surveillance programme.

Overall the public inquiry left the position of the different actors involved in the process substantially unaltered. Many parties, unhappy with the final decision, contended that the Planning Inspector had simply accepted the justifications put forward by the project promoter without undertaking a thorough investigation of whether there was a real need for a new port and whether the potential economic benefits of the port scheme would really outweigh the adverse effects on the environment (Dean, 2018). The economic growth agenda can thus be seen to have largely eclipsed any considerations of opening up the planning process to wider discussions of sustainability (Greenwood and Newman, 2010; Clutten and Tafur, 2012) and any effort to identify win-win or mutual gains solutions to contentious issues (Dean, 2018).

In 2006 P\&O was acquired by DP World, which then continued to take the port development programme forward. With DP World in charge for the London Gateway Port, further negotiations over the prerequisites and mitigation measures were necessary before final approval was given on 30th May 2007. Works on site were due to start in early 2009. However, in 2008, financial and economic downturns created considerable problems for DP World and its global expansion strategy, thus putting the programme at serious risk. Eventually a loan with the European Investment Bank had to be negotiated and secured to allow the scheme to go ahead (Gardiner, 2009). Construction works only started in 2010 , after a preparatory phase of almost a decade.

\section{MCA and Participatory MCA Methods}

The realm of MCA includes a range of different methods, techniques and tools, by which multiple objectives and decision criteria can be formally incorporated into the analysis of a problem. The 
MCA literature is rich with many different approaches, ranging from highly elaborate mathematical methods to simple and something even rough MCA applications (Dean, 2020). However, generally the large part of methods pertaining to this family incorporates the following elements:

- Option: recommended course of actions proposed in order to address a perceived problem and achieve an overarching end result.

- Objective: specific goal against which any proposed option is being assessed.

- Criterion: a specific measurable indicator of performances in relation to an objective, reflecting the extent to which an option meets the affiliated objective.

- Performance Score: a constructed measure pertaining to a given interval scale which identifies the performance of an option against a specific objective/criterion. High-performing options are ascribed high scores, whilst low-performing options score lower on the scale.

- Criterion Weight: a coefficient which is commonly intended to represent the level of importance of an objective and corresponding appraisal criterion (i.e. high-importance objectives and criteria are identified with high weights).

Typically, in a multi-criteria evaluation problem one or more project options are assessed against a number of different objectives, for which a set of evaluation criteria have been identified. The performances of an option against the various appraisal criteria, which can be assigned different weights, are evaluated by means of scores. Overall, what formally defines a multi-criteria method is the set of rules establishing the nature of options, objectives, criteria, scores and weights as well as the way in which objectives/criteria, scores and weights are used to assess, compare, screen in/out or rank options.

Likewise many other appraisal and evaluation techniques, MCA methods can be undertaken either in non-participatory (analyst-led) or participatory manner. In non-participatory assessments, the analysis is carried out autonomously by a research team of analysts and specialist advisors, according to a typical technocratic approach. A key argument in favor of this approach is that a group of scientists and trained specialists is best suited to make complex technical decisions. By contrast, participatory techniques adopt a more collaborative and (in principle more democratic) decision-making style, with the direct involvement of the different group decision-making participants (e.g. problem stakeholders and different categories of experts) in the analysis. In participatory MCA, group decision-making participants can thus contribute to the identification of the key elements of the multi-criteria framework (i.e. options, objectives and criteria, weights and scores). According to their proponents, participatory MCA methods present several important advantages over analyst-led MCA approaches and other traditional appraisal tools such as CBA:

- By taking explicit account of multiple objective and criteria, MCA can provide better insights into the nature of the problem at hand relative to mono-criterion and strictly monetary appraisal methods (Dimitriou et al., 2010 and 2016; Leleur, 2012). The inclusion of a participatory process in the analysis can then further enrich the multi-criteria framework, by leading to the identification of the full spectrum of interests and values in dispute, thus improving the overall quality and reliability of the appraisal exercise (Ward et al., 2016; Macharis and Baudry, 2018; Cornet et al., 2018b).

- MCA, by presenting a structure closely similar to the way humans have always been taking decisions, and making large use of tables and charts to display objectives, appraisal criteria, weights and scores as well as all the data and information employed during the analysis, provides a clearer and transparent approach to appraisal (Figueira et al., 2005; Dodgson et al., 2009; Dimitriou et al., 2010). When combined with MCA methods, deliberative procedures can 
enhance even more the transparency of the appraisal exercise (Stirling, 2006; Macharis et al., 2012; Macharis and Bernardini, 2015).

- Finally, the involvement of different stakeholders in the appraisal exercise is expected to promote mutual learning and build trust amongst the interested parties (McDowall and Eames, 2007; Barfod, 2018; Cornet et al., 2018b). It also supposed to increase the likelihood of acceptance of the results of the analysis by stakeholders themselves, as group decisionmaking participants are much more likely to take ownership of the decisions that emerge from the process (Macharis et al., 2010 and 2012; Macharis and Nijkamp, 2013).

On the other hand, as already highlighted, to date, empirical testing of participatory MCA techniques does not appear to have been very common. So far, only one study aimed at investigating (impartially and objectively) the strength and weaknesses of such methods (rather than promoting a new devised multi-actor multi-criteria method) has been published. This study, undertaken by Dean and colleagues (2019), has aroused doubts regarding many of the presumed benefits of participatory MCA techniques, contending that MCA and deliberative procedures should not be regarded as a panacea for better decisions.

\section{Key Features of the Participatory MCA Method Employed}

A multi-actor multi-criteria appraisal exercise can be undertaken in many different manners (see, amongst others, Salling, 2008; Dimitriou et al., 2010; Macharis et al., 2010 and 2012; Lami et al. 2011; Leleur, 2012; Barfod, 2012; Jensen, 2012; Jensen et al., 2013; Pensa et al., 2013; Barfod and Salling, 2015; De Brucker et al., 2015; Ward et al., 2016a and 2016b; Barfod, 2018; Cornet et al., 2018a and 2018b; Macharis and Baudry, 2018; Salling et al., 2018; Gatta et al., 2019)). Critical choices, potentially having a dramatic impact on the final results of the process, need to be made with reference to several aspects (Dean, 2018; Dean et al., 2019):

- Form of MCA employed: any participatory MCA exercise requires a balance to be made between the rigorousness of the analysis and the understandability of the process for the involved parties. Whilst relatively straightforward and easy to understand, simplistic MCA methods frequently entail several inconsistencies (e.g. double-counting of criteria; rough scoring and weighting procedures and questionable aggregation rules for scores and weights). By contrast, more sophisticated MCA methods are generally more consistent but, most of the times, are technically too complicated to be completely understood by non-experts people.

- Types of group decision-making participants involved: the actors involved in participatory MCA procedures typically comprise project stakeholders, namely individuals or groups of individuals who have a vested interest in the problem under examination and who can influence or are influenced by the outcomes of the decision-making process (Freeman, 1984). In some cases, also experts can be included as part of group decision-making participants with the view to incorporating a more scientific perspective on the problem at hand. Moreover, participants can take part in the process individually or as representative of organized groups (e.g. local community groups, government agencies, business groups, environmental experts).

- Selection of group decision-making participants: whilst proponents of participatory MCA methods (see, for instance, Macharis and Nijkamp, 2011) stress the importance of creating an inclusive appraisal exercise by involving all the affected and interested parties, the practical need for creating a manageable and efficient process limits drastically the number of group decision-making participants. In this regard a comprehensive review of participatory MCA techniques (Dean, 2018) have revealed that such processes rarely involve more than 30 
people, who participate in the process individually or as representatives of a few (i.e. 3-6) groups. The selection of group decision-making participants also implies largely arbitrary considerations on a number of interdependent factors, including the nature of the problem at hand, its geographical boundaries, and the main aspects to be prioritized (Stirling, 2006; Kahane et al., 2013). There is a persistent risk of missing stakeholder groups that instead should have been included and also the danger of reinforcing existing patterns of social and political disparities (Dean, 2018).

- Level of involvement of group decision-making participants: In participatory MCA methods, the involvement of stakeholders (and experts) can also be realized with different degrees of intensity (see Figure 2). Group decision-making participants can be given the possibility of affecting only partially the multi-criteria framework or, vice versa, they can be even offered the opportunity to provide an input for all the elements of the framework (i.e. options, objectives/criteria, weights and scores).

Figure 2 - Types of participatory MCA methods.

\begin{tabular}{|c|c|c|c|c|c|c|c|c|c|c|c|c|c|c|c|c|}
\hline \multirow{2}{*}{$\begin{array}{l}\text { Elements of the } \\
\text { MCA framework }\end{array}$} & \multicolumn{16}{|c|}{ Types of MCA } \\
\hline & $a$ & b & c & d & e & f & $\mathrm{g}$ & $\mathrm{h}$ & $\mathbf{i}$ & $j$ & $k$ & I & $\mathrm{m}$ & $n$ & 0 & $p$ \\
\hline \multicolumn{17}{|l|}{ Options } \\
\hline \multicolumn{17}{|l|}{ Objectives/criteria } \\
\hline \multicolumn{17}{|l|}{ Weights } \\
\hline Scores & & & & & & & & & & & & & & & & \\
\hline
\end{tabular}

Input from group decision-making participants (i.e. stakeholders and, in some cases, experts)

Input from the research team (i.e. analysts and specialist advisors)

Source: Adapted from Dean (2018).

- Participatory techniques employed to engage with participants: in order to engage with stakeholders (and experts) and elicit different types of valuation information from them, a large variety of participatory techniques, ranging from simple interviews and structured questionnaires to workshops and in-depth group discussions, can be employed.

- Strategies to include multiple perspectives in the multi-criteria framework: One of the most critical aspects of participatory MCA is represented by the ways in which the multiple group decision-making participants' perspectives are processed to determine the list of options, the value tree of objectives and appraisal criteria, and the sets of scores and weights. The points of view of the actors and groups taking part in the process can be kept separate from each other (i.e. single-actor views) with the view to highlighting better differences and similarities in the positions of the various group decision-making participants. Alternatively, stakeholders and experts' viewpoints can be aggregated together (either through discussions and negotiations 
between participants or in a more mechanical way by determining the 'average' between the various participants' preferences) in order to obtain a more practical synthesis between the positions of the various groups and actors (i.e. multi-actor view).

In general, there is not any best way to undertake a multi-actor multi-criteria process. Each approach implies both potential advantages and disadvantages. The appropriateness of the approach depends on the specific decision-making situation at hand as well as on the resource available to run the process.

In accordance with the large majority of the participatory MCA approaches proposed in the literature, in this multi-actor multi-criteria appraisal exercise, a simple MCA approach based on a linear aggregation rule was employed to facilitate the comprehension of the process also to nonexperts. According to this aggregation model, the overall performance of an option is computed as the weighted sum of the single performances of that option against each objective/criterion.

Furthermore, following Macharis and colleagues (2010), Ward and colleagues (2016a) and Cornet and colleagues (2018b), both project stakeholders and experts were involved in the process in the effort to combine and integrate knowledge derived from social interest advocacy with knowledge based on technical expertise. Several parties, spanning a diverse range of interests and perspectives were approached and invited to take part in the process. The practical impossibility of scheduling a general meeting (i.e. the people involved in the exercise have many business commitments, and live and work in different parts of the UK) led to the employment of individual interviews to engage with group decision-making participants. Whereas not allowing interactions between participants, the employment of individual interviews presents the advantage of enabling a more thorough investigation of each participant's interests and priorities, avoiding groupthink and providing confidentiality, which potentially encourages participants to share their view more openly with the research team leading the process.

Drawing on the method devised by Barfod (2018) and Cornet and colleagues (2018b) as well as on other approaches allowing ample scope for participation (see, for instance, Macharis et al., 2012; Ward et al., 2016a and 2016b), it was also decided to provide stakeholders and exprerts with the possibility to define objectives, weights and scores (Approach ' $L$ ' in Figure 2). Moreover, in the attempt to better capture the point of view of the stakeholders and experts taking part in the process, no attempt was made to aggregate together the participants' viewpoints (in terms of objectives, weights and scores) during the analysis. Several authors (see, amongst others, Stirling, 2006; Macharis and Nijkamp, 2011 and 2013; Macharis et al., 2012; Ward et al. 2016a; Cornet et al., 2018b) claim that this constitutes the most appropriate approach when the parties involved in multi-actor multi-criteria exercise are likely to present very different agendas and concerns.

Several summary tables (one for each participant) were ultimately employed to display the results of the process (i.e. single-actor views). At the end of the analysis, an overall multi-actor view was also obtained (for illustrative purpose only) by calculating the arithmetic mean of the single-actor views.

Specifically, the process adopted in this exercise encompassed the following key steps (see Figure 3):

- primary problem analysis (based on the London Gateway inquiry and preliminary interview with key project stakeholders);

- definition of the options to be appraised (undertaken by the research team);

- identification, mapping and engagement of group decision-making participants (consisting in stakeholders and experts); 
- selection of the objectives (undertaken by group decision-making participants);

- ascription of weights to the objectives (undertaken by group decision-making participants);

- assignment of scores to reflect the performances of each alternative against the different objectives (undertaken by group decision-making participants);

- aggregation of scores and weights (according to a simple additive weighted model) to obtain the global score of the options under study (multiple single-actor views produced).

Figure 3 - Steps of the participatory MCA exercise employed in this study.



\section{Application of the Participatory MCA Method to the Case Study}

\subsection{Primary Problem Analysis and Option Definition}

The participatory MCA method described above was applied to a hypothetical (on-going) appraisal of the London Gateway Port. It is important to emphasize that the scope of this exercise was not to undertake a revision of the decision-making process of this port complex (which was approved more than 10 years ago). Rather its purpose was simply to test the potential benefits and issues of participatory MCA methods through a comparison between the outcomes of actual planning and decision-making process of this port development programme with the results of a multi-actor multi-criteria appraisal exercise. In this appraisal exercise two mutually exclusive options were considered: 
- Option 1 entailed the construction of the London Gateway Port, whose main characteristics and impacts (see Table 1) were derived from the analysis of the public inquiry presented in Section 2, project reports, and interviews with experts and key project stakeholders.

- Option 2 consisted in a 'do-minimum' option, which assumed that there would be sufficient investments along the Themes to keep existing port and logistics infrastructure and facilities (particularly the Port of Tilbury - located upriver of the London Gateway Port and relatively close to it - see Figure 1) operational in the future.

The use of only two pre-selected options was also dictated by the need for limiting the complexity of the process and, at the same time, making it as realistic as possible. Indeed, whereas many proponents of participatory MCA often argue that one of key strengths of this methods is the possibility of identifying (based on participants' suggestions) new options not otherwise on the table (see, for instance, Stirling and Mayer, 2001), allowing participants to identify entirely new project alternatives, without any thorough assessment regarding their real technical feasibility, risks compromising the reliability and validity of the whole process (Yearley, 2001).

Table 1 - Key features of the two alternative options to be appraised.

\begin{tabular}{|c|c|c|c|c|}
\hline \multirow[t]{2}{*}{$\begin{array}{l}\text { Main Themes } \\
\text { and Issues }\end{array}$} & \multicolumn{2}{|c|}{$\begin{array}{c}\text { Option } 1 \\
\text { London Gateway Port } \\
\text { Construction of a new deep-sea container terminal } \\
\text { with an annual capacity of } 3.5 \text { million TEUs, a } \\
\text { logistics park and a port rail terminal. This proposal } \\
\text { also encompasses the upgrade of some major road } \\
\text { and rail links in the area and some dredging works } \\
\text { along the Thames. }\end{array}$} & \multicolumn{2}{|c|}{$\begin{array}{c}\text { Option } 2 \\
\text { 'Do-Minimum' Option } \\
\text { Sufficient investment to keep port and logistics } \\
\text { facilities along the Thames operational in the } \\
\text { future }\end{array}$} \\
\hline & Potential pros & Potential cons & Potential pros & Potential cons \\
\hline $\begin{array}{l}\text { Strategic } \\
\text { Alignment }\end{array}$ & $\begin{array}{c}\text { Possible important } \\
\text { contribution to the } \\
\text { objective of regenerating } \\
\text { the Thames Gateway } \\
\text { Area. }\end{array}$ & $\begin{array}{l}\text { The development } \\
\text { vision may not be } \\
\text { aligned with the } \\
\text { interests of the local } \\
\text { communities } \\
\end{array}$ & & $\begin{array}{c}\text { Minor contribution to the } \\
\text { objective of regenerating } \\
\text { the Thames Gateway } \\
\text { Area. }\end{array}$ \\
\hline $\begin{array}{c}\text { Port } \\
\text { Competitiveness }\end{array}$ & $\begin{array}{l}\text { Possible important } \\
\text { contribution to the } \\
\text { objective of increasing } \\
\text { the competitiveness of } \\
\text { London and the UK. }\end{array}$ & $\begin{array}{l}\text { There are too many } \\
\text { port expansion } \\
\text { projects in the UK. } \\
\text { This may lead to port } \\
\text { overcapacity in the } \\
\text { country. }\end{array}$ & $\begin{array}{l}\text { Given the current } \\
\text { state of the economy, } \\
\text { this options is likely } \\
\text { to ensure enough } \\
\text { port capacity in the } \\
\text { short- to medium- } \\
\text { term }\end{array}$ & $\begin{array}{c}\text { Possible loss of } \\
\text { competitiveness of } \\
\text { London and the UK port } \\
\text { system and possible risk } \\
\text { of capacity constraints if } \\
\text { container traffic will grow } \\
\text { again in future }\end{array}$ \\
\hline $\begin{array}{c}\text { Job } \\
\text { Opportunities }\end{array}$ & $\begin{array}{c}\text { The port complex is } \\
\text { expected to create about } \\
14,500 \text { new direct jobs } \\
\text { and approximately } 6,900 \\
\text { induced ones }\end{array}$ & $\begin{array}{l}\text { The types of jobs } \\
\text { provided may not be } \\
\text { aligned with the needs } \\
\text { of local communities. } \\
\text { The proposal may also } \\
\text { result in the closure of } \\
\text { other port facilities } \\
\text { across Thurrock }\end{array}$ & $\begin{array}{l}\text { No major risks of } \\
\text { local competition } \\
\text { between port and } \\
\text { logistics facilities } \\
\text { across Thurrock }\end{array}$ & $\begin{array}{l}\text { This option will not } \\
\text { provide many job } \\
\text { opportunities }\end{array}$ \\
\hline $\begin{array}{l}\text { Impacts on the } \\
\text { Marine } \\
\text { Environment }\end{array}$ & $\begin{array}{l}\text { Major mitigation } \\
\text { measures and monitoring } \\
\text { programmes have been } \\
\text { undertaken }\end{array}$ & $\begin{array}{c}\text { Potential adverse } \\
\text { effects on several } \\
\text { valuable natural areas, } \\
\text { marine and coastal } \\
\text { processes, and sea } \\
\text { quality }\end{array}$ & $\begin{array}{l}\text { Less impacts on } \\
\text { valuable natural } \\
\text { areas, marine and } \\
\text { coastal processes. }\end{array}$ & \\
\hline $\begin{array}{c}\text { Road Traffic, } \\
\text { Congestion and } \\
\text { Emissions }\end{array}$ & $\begin{array}{l}\text { The new port may take } \\
\text { hundreds of trucks off } \\
\text { (coming from other UK }\end{array}$ & $\begin{array}{l}\text { It may lead to more } \\
\text { traffic and congestion } \\
\text { in the Thames }\end{array}$ & $\begin{array}{l}\text { Less traffic and } \\
\text { congestion in } \\
\text { Thurrock } \\
\end{array}$ & $\begin{array}{c}\text { More trucks along } \\
\text { Britain's roads as the } \\
\text { majority of cargo directed }\end{array}$ \\
\hline
\end{tabular}




\begin{tabular}{|c|c|c|c|c|}
\hline & $\begin{array}{c}\text { ports and directed } \\
\text { towards the London } \\
\text { region) off Britain's roads. }\end{array}$ & Gateway Area. & $\begin{array}{c}\text { to London will continue to } \\
\text { come into Felixstowe and } \\
\text { Southampton and other } \\
\text { ports }\end{array}$ \\
\hline $\begin{array}{c}\text { Impacts on the } \\
\text { Landscape }\end{array}$ & $\begin{array}{c}\text { The option entails the } \\
\text { conversion and } \\
\text { regeneration of a former } \\
\text { oil refinery. }\end{array}$ & $\begin{array}{c}\text { The port complex will } \\
\text { have major impacts on } \\
\text { the landscape }\end{array}$ & $\begin{array}{c}\text { Less impacts on the } \\
\text { landscape }\end{array}$ & $\begin{array}{c}\text { No conversion and } \\
\text { decontamination of } \\
\text { industrial sites }\end{array}$ \\
\hline
\end{tabular}

\subsection{Identification and Engagement of Group Decision-Making Participants}

In Section 2 it has been illustrated that the planning and decision-making process of the London Gateway Port involved a complex networks of different actors and organizations, operating at different administrative levels and representing both the public and private sectors. Whilst including in the appraisal exercise all these different interests was deemed an unrealistic goal, noticeable effort was made to involve in the process a wide range of perspectives. Based on the analysis of key planning and policy documents and also on the availability of contact information the following people were approached and asked to take part in the process:

- a former National Government advisor, who had worked on the regeneration of Thames Gateway Region;

- a strategic planning manager working at the Greater London Authority (GLA);

- a member of the Thurrock Council;

- two former members of English Nature, who had been involved in the London Gateway inquiry;

- a former member of $\mathrm{P} \& \mathrm{O}$, who had been responsible for the planning of the London Gateway Port;

- three members of the local communities, who lives in the areas surrounding the new port complex;

- a planner, who had been involved in regeneration plans for the Thames Gateway Region;

- a transport and port expert who had conducted extensive research on the UK port system;

- an environmental expert with a good knowledge of the project under investigation;

- an economist and policy expert, who had carried out some studies on the Thames Gateway Region and the London Gateway Port;

However, not everybody accepted the invitation. The former member of P\&O refused to participate in the exercise, specifying that confidential or privileged information could not be disclosed. Whilst very keen to take part in some preliminary interviews over the planning and decision-making of the London Gateway Port, both the former members of English Nature decided not to take part in the process as they were quite skeptical on the real usefulness of the exercise. One of them in particularly argued that, in all probability, a participatory MCA process would not add anything to what had already emerged from the London Gateway inquiry. Scheduling constraints and pressures of work prevented the member of the Thurrock Council from taking part in the exercise. It was also not possible to involve in the multi-actor multi-criteria exercise any member of SPEAC as this environmental action committee had been closed down.

All the other people, who were guaranteed individual anonymity, accepted the invitation. Overall, as illustrated in Table 2, nine people (five project stakeholders and four experts), representing seven different interest groups, were involved in the multi-actor multi-criteria exercise. 
Notwithstanding this figure is substantially in line with those reported in many journal articles describing (practical or theoretical) applications of participatory MCA methods, it is evident that it cannot represent a statistically valid sample of the people involved or affected by the port development programme.

As above explained, getting stakeholder in same room at the same time was not possible. Therefore, the nine participants were involved in the exercise on an individual basis, between March and June 2017. For six people it was possible to carry out the exercise through face-to-face interviews. Each interview lasted approximately 2 hours and combined semi-structured discussions with the MCA appraisal exercise. The first part of each interview included an introduction to the case study and the key principles of MCA so as to ensure that both the problem under investigation and the participatory exercise were clear to the interviewees. The second part of the interview entailed the identification of objectives, weights and scores. For the remaining three people, due to scheduling constraints and pressures of work, the appraisal of the two options was conducted through a series of phone interviews (employed for explaining the nature of the exercise) and email questionnaires (used for the identification of objectives, and scoring and weighting procedures).

Table 2 - Group decision-making participants involved in the process.

\begin{tabular}{|c|c|c|}
\hline \multicolumn{3}{|c|}{ Group Decision-Making Participants } \\
\hline Categories & Groups & Number of People Involved \\
\hline \multirow{3}{*}{ Project Stakeholders } & National Government & $\begin{array}{c}1 \\
\text { (former National Government } \\
\text { advisor) }\end{array}$ \\
\hline & $\begin{array}{l}\text { Greater London Authority } \\
\text { (GLA) }\end{array}$ & $\begin{array}{c}1 \\
\text { (strategic planning manager at } \\
\text { GLA) }\end{array}$ \\
\hline & Local Communities & $\begin{array}{c}3 \\
\text { (people living in Thurrock, } \\
\text { participating on an individual } \\
\text { basis) }\end{array}$ \\
\hline \multirow{4}{*}{ Experts } & Planning Experts & 1 \\
\hline & Transport and Port Experts & 1 \\
\hline & Environmental Experts & 1 \\
\hline & Economists and Policy Expert & 1 \\
\hline
\end{tabular}

\subsection{Selection of the Objectives}

In this multi-actor multi-criteria exercise, the nine participants were asked to assess the two preselected project options against their own objectives and priorities. To assist stakeholders and experts in the appraisal exercise, a preliminary list of objectives was elaborated based on an analysis of some relevant (international, national, regional and local) planning and policy documents. The list also drew on the assessment principles and the standard appraisal framework designed by the UK's Department for Transport (DfT, 2003c), which, however, has the status of non-statutory advice, given the private and commercial nature of the UK's port sector. Overall, 19 project objectives belonging to three overarching appraisal dimensions, namely economic, environmental and social, were identified. These preliminary objectives, which were meant to 
represent only a guide for the group decision-making participants, are displayed in Table 3 . Participants were given the freedom to choose objectives from the list and also to identify entirely new project objectives, if they felt that additional objectives were necessary to capture further aspects of the problem. There was no restriction placed on the number and type of objectives which participants could select and/or specify.

Table 3 - List of preliminary objectives identified by the research team.

\begin{tabular}{|c|c|c|}
\hline \multicolumn{3}{|r|}{ Preliminary list of objectives } \\
\hline Dimensions & & Objectives \\
\hline \multirow{7}{*}{ Economic } & 1. & To increase the competitiveness of the UK, making it more attractive for business \\
\hline & 2. & To support London's role as a world city \\
\hline & 3. & To assist the regeneration of the Thames Gateway area \\
\hline & 4. & To increase the capacity of ports along the River Thames \\
\hline & 5. & To provide employment opportunities \\
\hline & 6. & $\begin{array}{l}\text { To provide benefits to all users of the port and surface transport system in terms of reduced } \\
\text { transportation costs and shorter in-transit times }\end{array}$ \\
\hline & 7. & To minimize the negative effect on competition between UK ports \\
\hline \multirow{6}{*}{ Environmental } & 8. & To minimize adverse effects on local air quality \\
\hline & 9. & To minimize noise and dusts \\
\hline & 10. & To protect the water environment \\
\hline & 11. & To maintain and enhance biodiversity \\
\hline & 12. & To improve flood safety \\
\hline & 13. & To encourage modal shift (from road to rail) for freight traffic \\
\hline \multirow{6}{*}{ Social } & 14. & To minimize risk to population surrounding ports \\
\hline & 15. & To improve health and safety record in ports \\
\hline & 16. & To minimize disruption to residents and businesses \\
\hline & 17. & To protect the character of the landscape and townscape \\
\hline & 18. & To protect the archeological and cultural heritage \\
\hline & 19. & To provide opportunities to local populations \\
\hline
\end{tabular}

\subsection{Weighting}

Once objectives had been established, stakeholders and experts were invited to ascribe weights to these objectives to reflect their relative importance. In MCA different weighting techniques can be adopted. Following Macharis and colleagues (2012), a fixed-point allocation system was initially adopted in this appraisal exercise. With this method each participants was asked to allocate a budget of 100 points over the selected criteria to reflect their relative importance. In particular, participants were required, first of all, to allocate these 100 points over the three appraisal dimensions (i.e. economic, environmental and social) and, successively, further split these amounts to the different objectives selected within each dimension. However, during the process it became clear that some people had difficulties in understanding and applying this technique. 
Therefore, in the attempt to reduce the complexity of the weighting process, a simple rating system was successively adopted. Under this new approach to weighting, stakeholders and experts were only required to rank the various objectives according to a 3-point scale, where 3 indicated very important criteria and 1 corresponded to slightly important criteria.

\subsection{Scoring}

Lastly, stakeholders and experts had to score the performances of the two project options against their list of objectives and corresponding appraisal criteria (which, however, given the rather qualitative nature of the exercise, were not explicitly identified by participants). In MCA, different interval scales can be employed for scoring the performances of the options. For this exercise a nine-point numerical scale, ranging from -4 (i.e. severe negative effects) to +4 (i.e. extremely positive effects) and with 0 used as neutral value (i.e. no significant effects), was adopted. Score were based on the information available and on the knowledge and experience of the various participants. As part of the scoring process, the parties involved were also asked to justify their scores as well as to provide any other comments they may have.

\subsection{Final Aggregation}

A simple weighted sum model was adopted to calculate the overall performance scores of the two project options based on the different objectives, score and weighting schemes identified by the group decision-making participants. The final results were then presented to participants, who were allowed to change some parameters of their multi-criteria framework if they were not happy with the resulting option ranking. The outcomes of the process are presented in the following section.

\section{Results of the process}

\subsection{Objectives}

Table 4 shows the objectives identified by the various project stakeholders and experts and the weights assigned by them to the selected objectives. As this table illustrates, only the representative of the Greater London Authority and the economist selected all the objectives included in the preliminary list prepared by the research team, whereas all the other group decision-making participants chose a relatively low number of objectives. The selection of objectives was strongly affected by the interests and perspectives of the participants. For instance, the environmental experts adopted mainly environmental objectives, whilst the transport expert selected for the most part economic objectives, openly admitting during the interview to consider this mainly as a transportation problem.

All the objectives included in the preliminary list were selected once by at least one person. However, only two objectives out of 19 , namely 'to assist the regeneration of the Thames Gateway area' and 'to encourage modal shift (from road to rail) for freight traffic' were included by all the different participants into their multi-criteria framework. Notwithstanding stakeholders and experts, in principle, had the possibility to propose their own objectives in addition to the ones included in the preliminary list, only one new objective, namely 'to guarantee security of supply' was added by the representative of the National Government. Hence, with the exclusion of this person, all the other participants only adopted objectives which had been identified by the research team at the beginning of the process. 


\subsection{Weights}

The different interests and priorities of the various participants also resulted in very different weighting schemes across the selected objectives. With the exception of the representative of the Greater London Authority, who considered the various objectives to have the same importance, all the other participants ascribed different weights to their objectives. As illustrated in Table 4, the representative of the National Government, the planners and the transport expert gave the highest weights to economic objectives, whilst the environmental expert ascribed the highest importance to environmental objectives. The economist seemed to pay more attention to economic and environmental aspects, whereas the members of the local community appeared somehow to be equally interested in all the three appraisal dimensions. A thorough comparison of the different weighting schemes is, however, difficult to make since, as indicated in the previous section, participants selected very different objectives. Interestingly enough, no objective was assigned the same weight by all respondents. 
Table 4 - Objectives and Weighting schemes adopted by the different group decision-making participants.

\begin{tabular}{|c|c|c|c|c|c|c|c|c|c|c|}
\hline \multirow[b]{2}{*}{ Dim.s } & \multirow[b]{2}{*}{ Objectives } & \multicolumn{9}{|c|}{ Group Decision-Making Participants } \\
\hline & & $\begin{array}{c}\text { National } \\
\text { Government }\end{array}$ & GLA & $\begin{array}{l}\text { Local com. } \\
\text { (1) }\end{array}$ & $\begin{array}{l}\text { Local com. } \\
\text { (2) }\end{array}$ & $\begin{array}{l}\text { Local com. } \\
\text { (3) }\end{array}$ & Planner & $\begin{array}{l}\text { Transport } \\
\text { Expert }\end{array}$ & $\begin{array}{l}\text { Env. } \\
\text { Expert }\end{array}$ & Economist \\
\hline \multirow{8}{*}{ Econ. } & $\begin{array}{l}\text { To increase the competitiveness of the UK, } \\
\text { making it more attractive for business }\end{array}$ & 3 & 3 & 1 & & 2 & 3 & & & 2 \\
\hline & To support London's role as a world city & & 3 & & & & & 2 & & 2 \\
\hline & $\begin{array}{l}\text { To assist the regeneration of the Thames } \\
\text { Gateway area }\end{array}$ & 2 & 3 & 3 & 3 & 2 & 1 & 3 & 2 & 3 \\
\hline & $\begin{array}{l}\text { To increase the capacity of ports along the } \\
\text { River Thames }\end{array}$ & & 3 & & & & 2 & & & 2 \\
\hline & To provide employment opportunities & 1 & 3 & 2 & 2 & & 1 & 3 & & 3 \\
\hline & $\begin{array}{l}\text { To provide benefits in terms of reduced } \\
\text { transportation costs and shorter in-transit } \\
\text { times }\end{array}$ & & 3 & 2 & & & 3 & & & 2 \\
\hline & $\begin{array}{l}\text { To minimize the negative effect on } \\
\text { competition between UK ports }\end{array}$ & & 3 & & & & & 1 & & 1 \\
\hline & * TO GUARANTEE SECURITY OF SUPPLY & 1 & & & & & & & & \\
\hline \multirow{6}{*}{ Env. } & $\begin{array}{l}\text { To minimize adverse effects on local air } \\
\text { quality }\end{array}$ & 1 & 3 & 2 & & & 2 & 2 & 2 & 3 \\
\hline & To minimize noise and dusts & & 3 & 1 & & 2 & & & 2 & 2 \\
\hline & To protect the water environment & & 3 & 3 & 2 & 3 & & & 3 & 3 \\
\hline & To maintain and enhance biodiversity & & 3 & & 2 & & 1 & & 3 & 3 \\
\hline & To improve flood safety & & 3 & & & & & & 2 & 3 \\
\hline & $\begin{array}{l}\text { To encourage modal shift (from road to rail) } \\
\text { for freight traffic }\end{array}$ & 1 & 3 & 2 & 2 & 2 & 2 & 2 & 2 & 3 \\
\hline \multirow{6}{*}{ Social } & $\begin{array}{l}\text { To minimize risk to population surrounding } \\
\text { ports }\end{array}$ & & 3 & & & 2 & & & 2 & 3 \\
\hline & To improve health and safety record in ports & & 3 & & & 2 & & & & 2 \\
\hline & $\begin{array}{l}\text { To minimize disruption to residents and } \\
\text { businesses }\end{array}$ & & 3 & & & & & & & 1 \\
\hline & $\begin{array}{l}\text { To protect the character of the landscape } \\
\text { and townscape }\end{array}$ & & 3 & & 3 & & & & 1 & 2 \\
\hline & $\begin{array}{l}\text { To protect the archeological and cultural } \\
\text { heritage }\end{array}$ & & 3 & & 1 & & & & 1 & 2 \\
\hline & To provide opportunities to local populations & & 3 & 2 & 3 & 3 & & 3 & & 2 \\
\hline
\end{tabular}

* Objectives identified by group decision-making participants, not included in the preliminary list (indicated in capital letters)

Objectives selected by group decision-making participants 


\subsection{Scores}

Likewise objectives and weights, performance scores clearly highlighted significant differences in the opinions amongst group decision-making participants. In general, there was no agreement on the performance of the two options against any objective. The scoring of individual options was influenced by the system boundaries and the timescale adopted (implicitly) by the participants and the different expectations concerning future maritime trade flows and economic conditions. In particular, according to the representative of the National Government, the London Gateway Port will perform well against all the selected objectives and will be particularly important to increase the competitiveness of UK, whereas the 'do-minimum' option would have represented a step backward for the country.

This above view was shared by the representative of the Greater London Authority, who also emphasized the particular critical role of the new port complex for the regeneration of the Thames Gateway Region. Interestingly enough, whilst initially selecting all the 19 objectives included in the preliminary list, this participant assigned a score of 0 to both the London Gateway Port and the 'dominimum' option against eight objectives. Therefore, only 11 objectives out of 19 turned out to be effectively relevant to compare the two project options.

The scores ascribed by the members of the local community, highlighted the trade-off between economic growth and environmental preservation (see Tables 5, 6 and 7). The 'do-minimum' alternative was considered by these three participants as an option able to minimize environmental impacts and preserve the local environment. In contrast, the London Gateway Port was generally recognized as a project potentially capable of fostering greater economic development and prosperity, even though all the three community members expressed concerns over the highdensity development vision envisaged for the Thames Gateway Region by the UK Government. It was, however, possible to identify some differences in the opinions of these people. For example, whereas two community members believed that the construction of the new port rail terminal and the improvement of the existing rail network would allow modal shift for freight traffic coming to/from the new port (Tables 6 and 7), the other member was rather skeptical on this possibility and pretty concerned about nuisances to local communities produced by the heavy road traffic (Table 5). A community member, who, at the time of the interview, differently from the other two members, was unemployed, was also the one to ascribe the highest score to the new port complex against the objective of 'providing opportunity to local populations' (Table 7).

Both the transport expert and the planner assigned relatively high scores to the performance of the London Gateway Port against economic objectives. The transport expert, however, differently from the planner, ascribed rather positive scores also to the 'do-minimum' option. According to this participant, notwithstanding a new modern port will probably be more attractive for major shipping companies, the existing port facilities along the Thames (above all, the Port of Tilbury) would have, however, been able to accommodate deep-sea container traffic at least in the short- to medium-term.

The environmental expert ascribed low scores to the performance of the London Gateway Port against the majority of selected objectives (mainly belonging to the environmental dimensions), based on the view that the new port complex does not comply with environmental sustainability criteria and the mitigation measures included as part of the port development programme will not be sufficient to avoid major negative impacts.

Extreme values for performance scores (i.e. +4 or -4 ) were rarely used by participants. The transport expert, the planners, the environmental expert and the economist all experienced difficulties in assigning numbers to the performance of the two options giving the huge 
uncertainties surrounding the future performance of the London Gateway Port, which is still under construction. Due to time constraints and the lack of exact data and specific information concerning several objectives the economist and policy expert was not able to complete the scoring procedure for the 'do-minimum' option.

Table 5 - Appraisal undertaken by a representative of the local community (1).

\begin{tabular}{|c|c|c|c|c|}
\hline \multicolumn{5}{|c|}{ Local Community Member (1) } \\
\hline \multirow[t]{2}{*}{ Dim. } & \multirow[t]{2}{*}{ Objectives considered } & \multirow[t]{2}{*}{ Weights } & $\begin{array}{c}\text { Option 1 } \\
\text { London Gateway } \\
\text { Port Complex } \\
\end{array}$ & $\begin{array}{c}\text { Option 2 } \\
\text { 'Do-Minimum' } \\
\text { Option } \\
\end{array}$ \\
\hline & & & Scores & Scores \\
\hline \multirow{4}{*}{ Econ. } & $\begin{array}{l}\text { To increase the competitiveness of the UK, } \\
\text { making it more attractive for business }\end{array}$ & 1 & +2 & +1 \\
\hline & $\begin{array}{l}\text { To assist the regeneration of the Thames } \\
\text { Gateway area }\end{array}$ & 3 & +2 & +1 \\
\hline & To provide employment opportunities & 2 & +1 & +1 \\
\hline & $\begin{array}{l}\text { To provide benefits to all users of the port } \\
\text { and surface transport system in terms of } \\
\text { reduced costs and shorter in-transit times }\end{array}$ & 2 & +2 & +1 \\
\hline \multirow{4}{*}{ Env. } & $\begin{array}{l}\text { To minimize adverse effects on local air } \\
\text { quality and greenhouses gases leading to } \\
\text { climate change }\end{array}$ & 2 & -1 & +1 \\
\hline & To minimize noise and dusts & 2 & -2 & -1 \\
\hline & To protect the water environment & 3 & -3 & -1 \\
\hline & $\begin{array}{l}\text { To encourage modal shift (from road to rail) } \\
\text { for freight traffic }\end{array}$ & 2 & +1 & +1 \\
\hline Social & To provide opportunities to local populations & 2 & +2 & +1 \\
\hline \multicolumn{3}{|c|}{ (Normalized) Unweighted Overall Performances } & +0.44 & +0.55 \\
\hline \multicolumn{3}{|c|}{ (Normalized) Weighted Overall Performances } & +0.26 & +0.47 \\
\hline
\end{tabular}

Table 6 - Appraisal undertaken by a representative of the local community (2).

\begin{tabular}{|c|c|c|c|c|}
\hline \multicolumn{5}{|c|}{ Local Community member (2) } \\
\hline \multirow[t]{2}{*}{ Dim. } & \multirow[t]{2}{*}{ Objectives considered } & \multirow[t]{2}{*}{ Weights } & $\begin{array}{c}\text { Option 1 } \\
\text { London Gateway } \\
\text { Port Complex } \\
\end{array}$ & $\begin{array}{c}\text { Option 2 } \\
\text { 'Do-Minimum' } \\
\text { Option } \\
\end{array}$ \\
\hline & & & Scores & Scores \\
\hline \multirow{2}{*}{ Econ. } & $\begin{array}{l}\text { To assist the regeneration of the Thames } \\
\text { Gateway area }\end{array}$ & 3 & +3 & -3 \\
\hline & To provide employment opportunities & 2 & +3 & -1 \\
\hline \multirow{3}{*}{ Env. } & To protect the water environment & 2 & -3 & +2 \\
\hline & $\begin{array}{l}\text { To maintain and enhance biodiversity and } \\
\text { meet the requirement of the Habitat directive }\end{array}$ & 2 & -3 & +2 \\
\hline & $\begin{array}{l}\text { To encourage modal shift (from road to rail) } \\
\text { for freight traffic }\end{array}$ & 2 & +3 & -1 \\
\hline \multirow{2}{*}{ Social } & $\begin{array}{l}\text { To protect the character of the landscape } \\
\text { and townscape }\end{array}$ & 3 & -3 & +3 \\
\hline & $\begin{array}{l}\text { To protect the archeological and cultural } \\
\text { heritage }\end{array}$ & 1 & -3 & +2 \\
\hline
\end{tabular}




\begin{tabular}{|c|c|c|c|}
\hline To provide opportunities to local populations & 3 & +1 & -1 \\
\hline \multicolumn{2}{|c|}{ (Normalized) Unweighted Overall Performances } & -0.25 & +0.38 \\
\hline \multicolumn{2}{|c|}{ (Normalized) Weighted Overall Performances } & 0 & +0.17 \\
\hline
\end{tabular}

Table 7 - Appraisal undertaken by a representative of the local community (3).

\begin{tabular}{|c|c|c|c|c|}
\hline \multicolumn{5}{|c|}{ Local Community Member (3) } \\
\hline \multirow[t]{2}{*}{ Dim. } & \multirow[t]{2}{*}{ Objectives considered } & \multirow[t]{2}{*}{ Weights } & $\begin{array}{c}\text { Option } 1 \\
\text { London Gateway } \\
\text { Port Complex } \\
\end{array}$ & $\begin{array}{c}\text { Option 2 } \\
\text { 'Do-Minimum' } \\
\text { Option }\end{array}$ \\
\hline & & & Scores & Scores \\
\hline \multirow{2}{*}{ Econ. } & $\begin{array}{l}\text { To increase the competitiveness of the UK, } \\
\text { making it more attractive for business }\end{array}$ & 2 & +3 & +1 \\
\hline & $\begin{array}{l}\text { To assist the regeneration of the Thames } \\
\text { Gateway area }\end{array}$ & 2 & +2 & +1 \\
\hline \multirow{3}{*}{ Env. } & To minimize noise and dusts & 2 & -3 & +1 \\
\hline & To protect the water environment & 3 & -4 & +1 \\
\hline & $\begin{array}{l}\text { To encourage modal shift (from road to rail) } \\
\text { for freight traffic }\end{array}$ & 2 & +3 & -1 \\
\hline \multirow{3}{*}{ Social } & $\begin{array}{l}\text { To minimize risk to population surrounding } \\
\text { ports }\end{array}$ & 2 & -2 & -1 \\
\hline & To improve health and safety record in ports & 2 & +1 & 0 \\
\hline & To provide opportunities to local populations & 3 & +3 & +1 \\
\hline \multicolumn{3}{|c|}{ (Normalized) Unweighted Overall Performances } & +0.38 & +0.38 \\
\hline \multicolumn{3}{|c|}{ (Normalized) Weighted Overall Performances } & +0.28 & +0.44 \\
\hline
\end{tabular}

\subsection{Final Rankings}

As explained above, a linear multi-criteria model was adopted to calculate the overall performance scores of the two project options. Specifically, unweighted and weighted overall performances were computed, respectively, as the arithmetic average of the different performances scores against the different project objectives and the weighted average of the single weighted scores against the different project objectives. The viewpoints taken by the different participants in terms of number and types of objectives, weights of these objectives and performance scores eventually led to very different option rankings. As a result of the analysis, the London Gateway Port turned out to be the preferred option for the representative of the National Government, the member of the Greater London Authority, the transport expert and the planner. In particular, the overall scores assigned to the 'do-minimum' option by the representative of the National Government, the member of the Greater London Authority and the planner were slightly negative, whilst the transport expert, as previously underlined, judged this option as however capable of delivering some benefits to the regional and national economy. By contrast, the results of the appraisal exercise undertaken by the members of the local communities and the environmental expert clearly indicated their preference for a better use of the existing port facilities over the London Gateway Port. Amongst these participants, the environmental expert clearly turned out to be the most critical about the new port. 
Table 8 illustrates the final option rankings produced by the various participants and the multiactor view. The global ranking was obtained by simply calculating the arithmetic mean of the overall performances of the single project options according to the point of view of the different participants. In the multi-actor view, the London Gateway Port ranked first.

Table 8 - Option rankings produced by the various participants and multi-actor view.

\begin{tabular}{|c|c|c|c|}
\hline \multirow{2}{*}{ Participants } & \multicolumn{2}{|c|}{ Weighted Overall Performances } & \multirow{2}{*}{$\begin{array}{c}\text { Preferred } \\
\text { Option }\end{array}$} \\
\cline { 2 - 3 } & $\begin{array}{c}\text { Option 1 } \\
\text { London Gateway } \\
\text { Port }\end{array}$ & $\begin{array}{c}\text { Option 2 } \\
\text { 'Do-Minimum' } \\
\text { Option }\end{array}$ & 1 \\
\hline National Government & +2.00 & -0.66 & 1 \\
\hline Greater London Authority & +1.68 & -0.74 & 2 \\
\hline Local Community (1) & +0.26 & +0.47 & 2 \\
\hline Local Community (2) & 0 & +0.17 & 2 \\
\hline Local Community (3) & +0.28 & +0.44 & 1 \\
\hline Transport Expert & +2.07 & +1.40 & 1 \\
\hline Planner & +0.94 & -0.27 & 2 \\
\hline Environmental Expert & -1.20 & +0.50 & 1 \\
\hline Economist and Policy Expert & -0.11 & - & $\mathbf{1}$ \\
\hline Global perspective* & $\mathbf{+ 0 . 6 6}$ & $\mathbf{+ 0 . 1 6}$ & $\mathbf{1}$ \\
\hline Global perspective** & $\mathbf{+ 0 . 7 5}$ & $\mathbf{+ 0 . 1 6}$ & \\
\hline
\end{tabular}

* including the perspective of the Economist and Policy Expert for Option 1

** excluding the perspective of the Economist and Policy Expert

\section{Discussion}

\subsection{Towards a More Holistic Appraisal?}

As highlighted in the Section 3, many authors contend that, compared to analyst-led tools and techniques, participatory MCA methods can lead to the employment of more comprehensive and holistic appraisal frameworks. However, in this case, it seems that the direct involvement of stakeholders and experts in the appraisal exercise did not increase the breadth of the appraisal compared to a purely analyst-led MCA approach. Indeed, the value trees adopted by the various participants turned out to be based almost exclusively on the objectives identified by the research team at the outset of the process (i.e. only one new objective was added by a participant).

It must also be noted that, although covering important policy domains, the preliminary list of 19 objectives was not prepared with the view to developing an exhaustive appraisal framework. Rather, the list was intended to serve only as a general guide for the group decision-making participants, who were then expected to review it, validate or reject some of these objectives and possibly incorporate additional objectives. Almost surely, some of the objectives included in the list 
could have been rephrased or expressed differently, and other additional objectives could have been added to account, amongst others, for economic efficiency and financial issues, feasibility and technical aspects and to encompass more detailed considerations regarding the possible implications for the water quality and the fishing industry in the Thames Estuary, the regeneration of the Thames Gateway Region and other wider development strategies. However, very limited input was obtained from participants in this regard.

\subsection{Towards a More Transparent and Clearer Approach to Decision-Making?}

Proponents of participatory MCA techniques also frequently contend that such methods can provide a more transparent and clearer approach to decision-making. In contrast, this process highlighted participants' hurdles and doubts concerning the use of MCA and their skepticisms over the exercise itself. As above explained, two former members of English Nature, who were quite skeptical on the nature and real usefulness of the exercise, decided not to take part in the exercise. A former member of $\mathrm{P} \& \mathrm{O}$, who was not willing to reveal sensitive data and information, also refused the invitation, despite the purely illustrative purpose of the appraisal exercise. Therefore, the assumption that in a real participatory MCA process, carried out as part of the planning and decision-making of a major project, project stakeholders, including project promoters and private sector parties, would accept to make their agendas totally public is at least questionable. In decision-making situations where stakes are high, multi-actor multi-criteria methods seem also dangerously exposed to the risks of bias and dishonesty, implying people setting (unintentionally or intentionally) scores and weights to increase the probability that a particular goal will occur or to put deliberately other parties at a disadvantage (Yearley, 2001). Whereas especially unintended biases are relatively easy to address (Montibeller and von Winterfeldt, 2015), strategic misrepresentations are much more difficult to correct and prevent.

Furthermore, as discussed above, during the process some participants also experienced problems with the weighting technique originally adopted, so that it was deemed necessary to replace it with a simpler one. A few people also had difficulties in understanding the differences between scores and weights, and several concerns were expressed over the fact that numeric scales were inappropriate to really capture all the different issues and aspects entailed by the London Gateway Port. As already pointed out in Section 6.3, data and information available to express a judgement over the performances of the project options, were also considered, in many cases, insufficient for assigning meaningful and realistic scores.

The identification of objectives was also problematic in some respects. The economist and the representative of the Greater London Authority were the people who selected the highest number of objectives. However, the former was unable to complete the analysis due to time constraints, whereas, as explained in Section 6.3, some concerns emerged over the actual use of the selected objectives by the representative of the Greater London Authority. Overall, eight participants out of nine did not add any new objective and only adopted objectives originally identified by the research team. It is largely debatable whether the reason for this rests on a general satisfaction of participants with the preliminary list of objectives, or lies instead on the relatively limited time available to undertake the exercise and problems with formulating meaningful and specific goals. In any case, based on the insights of the interviews, it can be argued that, had participants been asked to develop autonomously their objectives from scratch, almost certainly the process would have turned out to be much more difficult to manage and complete.

Overall, all these aspects ineluctably pose serious doubts over the reliability of the final results produced by this participatory exercise. On the one hand, it can be contended that by providing 
participants more time to familiarize themselves with the exercise, it would have been possible to obtain better and more reliable outcomes. On the other hand, had the process been longer, securing engagement from the participants would have probably been even harder (with the chosen structure, already one of the participants found it impossible to complete the exercise entirely).

\subsection{Towards Better and More Legitimate Decisions?}

The multi-criteria exercise provided ample scope for participation. Indeed, whilst options were defined in advance, group decision-making participants were given the opportunity to identify their own objectives, weights and scores. Subject to the inconsistencies and reliability issues discussed above, Tables 5-7 and all the other tables illustrating the point of view of the other participants (not presented in this paper) could have potentially provided a hypothetical decision-maker with a wide array of information concerning the way the different stakeholders framed the problem, in line with what contended by several proponents of participatory MCA methods (see, for example, Macharis and Nijkamp, 2013; Macharis et al., 2012; Cornet et al., 2018b). However, at least two points need to be made here. First of all, these tables do not seem to add much to what had already emerged from the London Gateway inquiry. The analysis of the planning and decision-making process of this new port complex, presented in Section 2, had already highlighted the existing tensions between the potential economic, transport and regeneration benefits of the port development programme, and its possible negative implications for the environment and local communities. Hence, the fact that the representative of the National Government, the member of the Greater London Authority and the transport expert ultimately selected the London Gateway Port as the preferred option, whereas members of the local communities and the environmental expert opted instead for a 'do-minimum' option is not surprising. Probably several other aspects could have easily been predicted at the outset of the participatory MCA process, including the great attention paid by the environmental expert to environmental objectives, the considerable importance given by the transport expert to the transport and economic dimensions of the problem, the major concerns expressed by the local community members regarding the possible local impacts of the London Gateway Port and, at the same time, their (moderate) hope for possible job opportunities provided by the new port complex.

Secondly, it must be acknowledged that any appraisal exercise, irrespectively from the specific method adopted (e.g. CBA; analyst-led or participatory MCA), is typically undertaken with the view to supporting decisions on future actions. However, it is absolutely unclear how a decision-maker (e.g. a Planning Inspector or a Government Minister) could have ideally used the tables and charts displaying the different single-actor views to arrive at a final decision on the best course of action for London and the UK port system. Indeed, these tables clearly illustrate that a dramatic difference of opinion exist amongst the various group decision-making participants. Even between the members of the local communities there is little agreement over the parameters of the analysis. Processing systematically and comprehensively these constellations of opinions (i.e. nine different lists of objectives, nine different weighting schemes, nine sets of scores and, consequently, nine different project rankings) with the view to deriving clear conclusions turns out to be extremely problematic. Pursuing this aim when the process involves a higher number of parties (as a participatory MCA process on a large-scale transport project or another major policy problem would theoretically require) become even more complicated, if not impossible.

The necessity of reconciling and synthetizing, somehow, these different multi-criteria frameworks so as to obtain only a few parameters and indicators, most usefully oriented towards 
the aim of providing decision justification, is thus incontrovertible. Following the method proposed by Macharis (Macharis at al., 2010 and 2012; Macharis and Baudry, 2018) as well as many other participatory MCA techniques proposed in the literature (see, amongst others, Stirling and Meyer, 2001 and Mcdowall and Eames, 2007), in this exercise a multi-actor view has been obtained by simply aggregating together, in a rather mechanical way, the various single-actor views. However, as demonstrated by Arrow (1951) in his 'Impossibility Theorem', a mathematical aggregation of individual preferences (e.g. an arithmetic average) in the attempt to derive a group preference does not constitute a particularly consistent approach. Indeed, this approach is unable to either address the conflicts of interests of different participants or reconcile the divergent frames of references, which these actors employ. In this case, for example, the selection of the London Gateway Port as the preferred option in the aggregated analysis (see Table 8) should not be seen as a compromising solution as it leaves many of the concerns expressed by the members of the local community and the environmental expert totally unanswered. Hence, with this type of approach to participatory MCA, conflicts between participants are quite likely to re-emerge at a later stage.

As illustrated in Section 4, another possible approach to produce an overall multi-actor view is through discussions and negotiations between participants. In this specific case, this approach, which draws heavily on ideas of communicative and collaborative planning theories and deliberative and discursive democracy (see Forester, 1999; Healey, 1998 and 2003; Innes, 1996; Innes and Booher, 2003), was not employed due to the practical impossibility of getting stakeholders and experts in the same room. However, given this huge clash of values, the assumption that participants' discussions would have led, in sharp contrast to what actually happened in the London Gateway inquiry, to the identification of a shared list of objectives, a common weighting scheme, a conjoint set of performance scores and ultimately to a mutually convenient solution and clear recommendations, upon which decision-makers could have then acted, appears excessively optimistic.

Discussions and speculations over the effective possibility of producing consensus amongst group decision-making participants should also take into account the fact that the employment of MCA in a participatory appraisal exercise, by forcing people to frame the problem under investigation in a rather simplistic and schematic manner (i.e. in terms of options, objectives, weights and scores), implicitly tends to hide or underplay many important differences between participants' viewpoints, which otherwise would probably be more evident. In this case, for instance, the fact the group decision-making participants were assessing the same project options, did not ensure that they were actually adopting the same system boundaries. Indeed, from the discussions and interviews carried out as part of the process, it was apparent that, compared to the members of the local communities, other participants such as the representative of the National Government, the member of the Greater London Authority, the planner and the port expert framed the London Gateway Port at a much higher planning scale, including in their analysis also considerations about other national ports and transport infrastructure, and issues related to international shipping and global supply chain. The fact that different stakeholders and experts agreed on some general objectives also does not necessarily imply that they were really sharing the same goals. For example, whilst everybody identified the 'regeneration of the Thames Gateway area' as an important objective, participants expressed a wide variety of development visions for that region. Hence, just to cite a few cases, the representative of the Greater London Authority adopted this objective assuming the possibility of delivering hundred thousands of new jobs and homes as envisaged by numerous planning and policy documents, whereas all the members of the local communities clearly supported a much lower density development scenario. Lastly, as described in Section 6.3, there were also major differences, surely bigger than those captured by a 
numerical scale, in the assumption employed by participants during the assessment of the performances of the options against the different objectives (e.g. timescales adopted for appraisal; and possible future economic, social and political conditions, all having huge impacts on the container shipping industry).

\subsection{Subjectivity in Participatory MCA}

One of the most critical and well-known weaknesses of MCA is the lack of universally accepted guidelines concerning the definition of the key elements of the analysis. In the course of time, difficulties in establishing standard rules for selecting appropriate weighting schemes and other parameters have hampered the use of MCA for transport project appraisal in several countries (Dean, 2020). In this regard, the participatory exercise allowed to shed further light on the arbitrary and subjective nature of MCA and participatory MCA methods in particular. Indeed, all the choices made concerning the structure of the process and discussed in Section 4, although motivated by the purpose and constraints of the exercise, were totally discretionary. Had the process been carried out in a different manner, almost certainly totally different outcomes would have been produced. For instance, the involvement of more groups and actors opposing to the London Gateway Port (e.g. SPEAC) in the process, would have probably dragged down the aggregate overall performances of new port complex in the multi-actor view (although, as already indicated, the meaning of this global score is largely questionable), leading to the identification of the 'dominimum' option as the preferred course of action. Totally different results would have also been obtained if it was decided to, for example, involve in the appraisal exercise only project stakeholders, thus excluding experts from the analysis, and/or allow group decision-making participants to only define objectives and weights, thus leaving to the research team the responsibility for determining performance scores.

The simple weighted additive MCA technique employed, the weighting and scoring procedures adopted and the interval scales used for weights and scores also represented largely arbitrary decisions, which had noticeable impacts on the outcome of the process. For example, the possibility of effectively using the 100-point allocation method for determining weights, in place of a 3-point scale rating system, could have substantially altered the overall performances of the project options. Indeed, whereas rather simple to use, a 3-point scale is clearly too narrow to entirely capture differences in the positions of the different group-decision making participants. It is also evident that the use of a different interval scale for scores (e.g. an 11-point scale ranging from 0 to 10 in place of the nine-point scale actually adopted) could have changed even substantially the results of the scoring process.

\subsection{Underlying Assumptions of Participatory MCA methods}

Finally, this case study also highlighted the apparent contrast between the ideal approach to planning, appraisal and decision-making of major transport projects and the realities of such projects. On the one hand, proponents of participatory MCA methods quite frequently present them as an approach capable of tackling project complexity. On the other hand, as shown in Section 4, such methods implicitly adopt a rational-comprehensive problem-solving approach, based on several simplistic assumptions:

- The process is assumed to be entirely led by an independent research team and implies a clear, linear and logical sequence of steps, starting with the identification of a problem, and ending with the selection of the 'best' course of action to 'solve' it. 
- The research team is supposed to have adequate skills and resources for analyzing a given problem at hand by collecting all the necessary information and identifying and mapping all the project stakeholders.

- The participatory MCA exercise is presumed to be undertaken in a society where all the different interests and priorities are (or can be made) clear and well-articulated. Moreover, no substantial power imbalances exist between the stakeholders, who appear to behave as purely passive actors, limiting themselves to provide the research team with data and information concerning their interest and priorities.

- The number and types of stakeholders, their preferences as well as all the other key parameters of the analysis are implicitly expected to remain fixed (or relatively stable) during the whole decision-making process period.

In contrasts, as documented by many studies (see, amongst other, Koppenjan and Klijn, 2004; Van Gils and Klijn, 2007; Dean, 2018) and also showed in Section 2, planning and related decision-making procedures concerning large-scale transport projects are highly fragmented. They imply, in other words, a number of mutually interdependent actors operating at different administrative levels, multiple discussions over arrays of intertwined issues and numerous coupled decision arenas whose outcomes cannot be completely captured by using a list of criteria and a set of weighted scores.

In light of this fragmentation, it is also hardly possible for a single party to steer completely the decision making process (Dean, 2018). The individuals and groups of individuals who have a vested interest in the problem, in many cases, are not passive actors, but rather they actively concur to shape the problem definition as well as its solution through a process of mutual influence and negotiation (Miller and Lessard, 2000; Lessard and Miller, 2013). Often, then, incentives for strategic and uncooperative behaviors and for misrepresenting data and information (e.g. parties not taking part in the participatory MCA or refusing to disclose entirely their objectives) are high. The most powerful actors typically tend to use their influence opportunistically to turn possible conflicts to their own advantages (Altshuller and Luberoff, 2003; Dwarka and Feitelson, 2013; Nobbe, 2014).

In addition, major projects typically involve a long-term and thus highly uncertain perspective. For projects whose preparation and construction require one or even several decades, the possibility of making reliable predictions about the future effects and consequences remains extremely limited (de Bruijn and Leijten, 2008; Samset, 2010; Martens and van Weelden, 2014). In the absence of sound and widely respected information on the effects of the proposal(s) under examination, a participatory MCA process (but also any other appraisal exercise or any other participatory procedure) can easily break down into a purely vague and rhetorical debate.

The long development cycle of major transport projects also has major implications for any appraisal exercise. During the years comprised between initial project conception and final project approval, stakeholders' problem perception, agenda, role, mutual relationships and also stakeholder groups themselves (including the project promoters as in the case of the London Gateway Port) are likely to change, even substantially (Priemus, 2010; Hertog and Westerveld, 2010; Dimitriou et al., 2011). It is thus evident that, in a participatory MCA exercise, tables and charts illustrating the perspectives of the single actors and/or the multi-actors view represent exclusively a snapshot of (some) stakeholders' opinions at a particular point in time. Accordingly, to really map stakeholders and their perception it would be necessary to repeat the process on regular basis. However, this would turn out to be costly and extremely complicated to realize in practice. 


\section{Conclusions}

This article has illustrated an application of participatory MCA to the appraisal of the London Gateway Port. Similarly to the study undertaken by Dean and colleagues (2019), the findings of this multi-actor multi-criteria appraisal exercise do not seem to support many of the key arguments put forward by proponents of such methods (i.e. comprehensiveness, inclusivity, clarity and transparency of the process). In particular, from this analysis the following issues were identified:

- The participatory appraisal exercise did not lead to a comprehensive assessment of project proposals. Many important aspects, typically recognized and assessed during a conventional appraisal process were not included in the multi-criteria frameworks developed by stakeholders and experts.

- Several people experienced difficulties in understanding the basic principle of MCA, with consequent doubts over the reliability of the outcome of the process.

- The outcome of the process also did not add any critical information that had not already been emerged from the analysis of the London Gateway inquiry.

- Due to the practical impossibility of identifying and involving in the process all the affected and interest parties, a multi-actor multi-criteria appraisal exercise of any large-scale transport project (or another major policy problem) risks even representing a step backwards with reference to democracy and equity.

- The case study also showed that MCA, by forcing people to frame the problem under investigation in a rather simplistic and schematic manner (i.e. in terms of options, objectives, weights and scores), is likely to exclude critical information, essential for arriving at a rich representation of the problem at hand, and tends to hide or underplay many important differences between participants' viewpoints (e.g. overarching visions and goals; system boundaries; time horizons considered and other key hypothesis and assumptions), which otherwise would be much more evident. This can become problematic especially in decisionmaking situations where the parties involved have diverging belief and value systems (i.e. a typical decision-making process regarding a large-scale transport project, involving a number of actors and agencies, whose relationships turn out to be partially or even entirely adversarial).

- Questions were also raised over the real willingness of stakeholders to share entirely their agendas during a multi-actor multi-criteria exercise carried out as part of a real decisionmaking process. Therefore, it is rather debatable whether such methods could really represent a more transparent approach to appraisal.

- A participatory multi-criteria appraisal exercise also does not seem to be capable of leading to more informed and legitimate decisions than conventional public consultation and planning inquiry procedures. As above illustrated, allowing group decision-making participants to frame the problem according to their own perspective, whilst representing a democratic and holistic approach to appraisal, does not point clearly to any constructive way forward to reach a decision on the problem at hand. By comparison, the mathematical aggregation of the various participants' preferences is theoretically weak and extremely likely to lead to a compromise that is uncomfortable and unstable. Finally, it is possible to contend that, although not tested in this exercise, a negotiation process carried out in the attempt to produce a common multicriteria framework is extremely challenging to manage and implies high chances of deadlock, especially when stakeholders present totally opposite interests, with little room for compromise. 
- The process has also further emphasized the arbitrariness of MCA and participatory MCA, showing that there are a number of variables (e.g. number and types of group decision-making participants; weighting and scoring procedures; level of participants involvement; and approach adopted to handle the participants' point of view), whose selections can alter dramatically the results of the process.

- Lastly, it is also difficult to see how the linear and regular character of participatory MCA methods could fit the turbulent, fragmented, unstructured and highly uncertain nature of major transport project decision-making.

As highlighted throughout the paper, there were a number of limitations associated with this multi-actor multi-criteria exercise. The process involved only nine people, who, due to their business commitments had only a relatively limited amount of time to complete the MCA exercise. It was also impossible to have mutual interactions and discussions between participants. Hence, on the one hand, especially with reference to the first three issues listed above, it would be possible to argue that a more rigorous process (entailing, for instance, the involvement of a greater number of stakeholders and experts, the possibility of iterating the process several times, more time for interviews and also the opportunity to include some discussions between participants) is extremely likely to increase the breadth and depth of the assessment and ultimately lead to some critical insights into the problem at hand.

On the other hand, all the other issues which have been identified, although based on a single case study approach, appear to be rather general and consequently are likely to affect any participatory MCA process, irrespectively from the manner in which the process is undertaken. These issues also are much more difficult to tackle and address completely. Therefore, whereas further empirical research in the application of multi-actor multi-criteria techniques is surely needed and recommended, the potential contribution that such methods can provide to the improvement of decision-making for major transport infrastructure seems to be limited at best. Participatory MCA procedures should only be used to complement and integrate the information derived from traditional appraisal methods and well-established consultation procedures, and preferably employed only to examine specific and self-contained aspects entailed by the transport project which is being assessed. 


\section{References}

Altshuller, A. and Luberoff, D. (2003). Mega-Projects: The Changing Politics of Urban Public Investment. Brookings Institution Press.

Annema, J.A, Koopmans, C., and Van Wee, B. (2007). Evaluating Transport Infrastructure Investments: The Dutch Experience with a Standardized Approach. Transport Reviews, Vol. 27, No. 2, pp. 125-150.

Arrow, K. (1951). Social Choice and Individual Values. John Wiley \& Sons.

Asteris, M. and Collins, A. (2007). Developing Britain's Port infrastructure: Markets, Policy, and Location. Environment and Planning A, Vol. 39, No. 9, pp. 2271-2286.

Barfod, M. (2018). Sustainable Transport Planning: Involving Stakeholders in the Decision Support Process Using Planning Workshops and MCDA. Transport, Vol. 33, No. 4, pp. 1052-1066.

Barfod, M.B. (2012). Optimising Transport Decision Making using Customised Decision Models and Decision Conferences. Ph.D. Dissertation. Department of Transport, Technical University of Denmark.

Barfod, M.B. and Salling, K.B. (2015). A New Composite Decision Support Framework for Strategic and Sustainable Transport Appraisals. Transportation Research Part A, Vol.72, No. 1, pp.1-15.

Clutten, R. and Tafur, I. (2012). Are Imperative Reasons Imperiling the Habitat Directives? An Assessment of Article 6(4) and the IROPI Exception. In: Jones, G. (Ed.), The Habitat Directive: A Developer's Obstacle Course?. Hart Publishing, pp. 167-182.

Cornet, Y., Barradale, M., Barfod, M. and Hickman, R. (2018a). Giving Future Generations a Voice: Constructing a Sustainability Viewpoint in Transport Appraisal. European Journal of Transport and Infrastructure Research, Vol. 18, No. 3, pp. 316-339.

Cornet, Y., Barradale, M., Gudmundsson, H. and Barfod, M. (2018b). Engaging Multiple Actors in LargeScale Transport Infrastructure Project Appraisal: An Application of MAMCA to the Case of HS2 HighSpeed Rail. Journal of Advanced Transportation. Vol. 18, pp. 1-22.

Coxon, A. (2007). Gateway Port gets the Green Light. URL: http://www.placemakingresource.com/article/661208/gateway-port-gets-green-light (Retrieved 18/9/2016).

DCLG (Department for Communities and Local Government) (2007a). Thames Gateway Delivery Plan. DCLG Publications.

DCLG (Department of Communities and Local Government) (2007b). The Investor's Guide to the Gateway. DCLG Publications.

De Brucker, K. and Verbeke, A. (2006). The Eclectic Multi-criteria Analysis (EMCA): A Tool for Effective Stakeholder Management in Project Evaluation. In: Notteboom, T. (Ed.), Ports are more than Piers. DeLloyd, 211-234.

De Brucker, K. and Verbeke, A. (2007). The Institutional Theory Approach to Transport Policy and Evaluation. The Collective Benefits of a Stakeholder's Approach: Towards an Eclectic Multi-criteria Analysis. In: Haezendonck, E. (Ed.), Transport Project Evaluation - Extending the Social Cost-Benefit Approach. Edward Elgar, pp. 55-94.

De Brucker, K., Macharis, C. and Verbeke, A. (2015). Two-Stage Multi-Criteria Analysis and the Future of ITS-based Safety Innovation Projects. IET Intelligent Transport Systems, Vol. 9, No. 9, pp. 842-850.

De Bruijn, H. and Leijten, M. (2008). Mega-Project and Contested Information. In: Priemus, H., Flyvbjerg, B., and van Wee, B. (Eds.), Decision-Making on Mega-Projects: Cost-Benefit Analysis, Planning and Innovation. Edward Elgar, Cheltenham, pp. 84-104.

De Bruijn, H. and Leijten, M. (2008). Mega-Project and Contested Information. In: Priemus, H., Flyvbjerg, B. and van Wee, B. (Eds.), Decision-Making on Mega-Projects: Cost-Benefit Analysis, Planning and Innovation. Edward Elgar, Cheltenham, pp. 84-104.

Dean, M. (2018). Assessing the Applicability of Participatory Multi-Criteria Analysis Methodologies to the Appraisal of Mega Transport Infrastructure. Ph.D. Dissertation. The Bartlett School of Planning, University College London. URL: 
https://www.academia.edu/42992356/Assessing_the_Applicability_of_Participatory_MultiCriteria_Analysis_Methodologies_to_the_Appraisal_of_Mega_Transport_Infrastructure

Dean, M. (2020). Trends and Applications of Multi-Criteria Analysis in Transport Policy and Planning. In: Mouter, N. (Ed.), Advances in Transport Policy and Planning: Appraisal Methods. Elsevier, Ch. 6. (Forthcoming).

Dean, M., Hickman, R. and Chen C.-L. (2019) Testing the Effectiveness of Participatory MCA: The Case of the South Fylde Line. Transport Policy, Vol. 73, pp. 62-70.

DfT (Department for Transport) (2003a) London Gateway Inquiry Inspector's Report: Volume 1. URL: http://webarchive.nationalarchives.gov.uk/+/http:/www.dft.gov.uk/pgr/shippingports/ports/ir/lgi/londongate wayinquiryinspecto4954 (Retrieved: 15/11/2016).

DfT (Department for Transport) (2003b) London Gateway Inquiry Inspector's Report: Volume 2. URL: http://webarchive.nationalarchives.gov.uk/+/http://www.dft.gov.uk/pgr/shippingports/ports/ir/lgi/londongate wayinquiryinspecto4955 (Retrieved: 15/11/2016).

DfT (Department for Transport) (2003c). A Project Appraisal Framework for Ports. The Stationery Office, London.

DfT (Department for Transport) (2017). Transport Investment Strategy - Moving Britain Ahead. Presented to Parliament by the Secretary of State for Transport by Command of Her Majesty. Crown.

Dimitriou, H.T. (2009). Globalization, Mega Transport Projects and Private Finance. Paper presented at the 'VREF (Volvo Research Volvo Research and Educational Foundations) 4th International Conference on Future Urban Transport', Gothenburg, Sweden, April 19-21.

Dimitriou, H.T., Ward, E.J. and Dean, M. (2016). Presenting the Case for the Application of Multi-Criteria Analysis to Mega Transport Infrastructure Appraisal. Research in Transportation Economics, Special Edition. Vol. 58, pp. 7-20.

Dimitriou, H.T., Ward, E.J., Wright, P. (2010). Incorporating Principles of Sustainable Development within the Design and Delivery of Major Projects: An International Study with particular reference to Major Infrastructure Projects for the Institution of Civil Engineering and the Actuarial Profession. OMEGA Centre, The Bartlett School of Planning, University College London.

Dimitriou, H.T., Ward, E.J., Wright, P. (2011). Lessons for Decision-makers: A Comparative Analysis of Selected Large-scale Transport Infrastructure Projects in Europe, USA and Asia-Pacific. OMEGA Centre, The Bartlett School of Planning, University College London.

Dodgson, J.S., Spackman, M., Pearman, A. and Phillips, L.D. (2009). Multi-Criteria Analysis: A Manual. Department for Communities and Local Government: London.

DTLR (Department of Transport, Local Government and the Regions) (2001). Recent Developments and Prospects at UK Container Ports. DTLR Publications.

Dwarka, K. and Feitelson, E. (2013). The Political Economy of Urban Infrastructure. In: Priemus, H. and van Wee, B. (Eds.), International Handbook on Mega-Projects. Edward Elgar, pp. 158-181.

Figueira, J., Greco, S., and Ehrgott, M. 2005. Introduction. In Figueira, J., Greco, S., and Ehrgott, M. (Eds.), Multiple Criteria Decision Analysis: State of the Art Surveys. Springer, pp. xxi- xxxiv.

Flyvbjerg B., Bruzelius N. and Rothengatter W. (2003). Megaprojects and Risk - An Anatomy of Ambition. Cambridge University Press.

Forester, J. (1999). The Deliberative Practitioner: Encouraging Participatory Planning Processes. The MIT Press.

Gardiner, J. (2009). Government Set to Rescue £1.5bn Essex Port Scheme. URL: http://www.building.co.uk/news/government-set-to-rescue-\%C2\%A315bn-essex-portscheme/3147957.article (Retrieved: 20/11/2016).

Gatta, V., Marcucci, E., Delle Site, P., Le Pira, M., and Carrocci, C.S. (2019). Planning with Stakeholders: Analysing Alternative Off-Hour Delivery Solutions via an Interactive Multi-Criteria Approach. Research in Transportation Economics, Vol. 73, pp. 53-62.

Greenwood, D. and Newman, P. (2010). Markets, Large Projects and Sustainable Development: Traditional and New Planning in the Thames Gateway. Urban Studies, Vol. 47, No.1, pp. 105-119.

Hall, P. (1980). Great Planning Disasters. University of California Press. 
Healey, P. (1998). Collaborative Planning in a Stakeholder Society. The Town Planning Review, Vol. 69, No. 1, pp. 1-21.

Healey, P. (2003) Collaborative Planning in Perspective. Planning Theory, Vol. 2, No.2, pp. 101-123.

Hertogh, M.J.C.M. and Westerveld, E. (2010). Playing with Complexity. Management and Organisation of Large Infrastructure Projects. Erasmus University Rotterdam.

Hickman, R. (2019). The Gentle Tyranny of Cost-Benefit Analysis in Transport Appraisal. In: Docherty, I. and Shaw, J. (Eds.), Transport Matters. Policy Press, pp. 131-152.

Hickman, R. and Dean, M. (2018) Incomplete Cost - Incomplete Benefit Analysis in Transport Appraisal. Transport Reviews, Vol. 38, No. 6, pp. 689-709.

Innes, J.E. (1996) Planning through Consensus Building: A New View of the Comprehensive Planning Ideal, Journal of the American Planning Association, Vol. 62, No.4, pp. 460-472.

Innes, J.E. and Booher, D.E. (2003). Collaborative Policymaking: Governance through Dialogue. In: Hajer, M.A. and Wagenaar, H. (Eds.), Deliberative Policy Analysis - Understanding Governance in the Network Society. Cambridge University Press, pp. 33-59.

Jensen, A.V. (2012). Appraisal of Transport Projects: Assessing Robustness in Decision Making. Ph.D. Dissertation. Department of Transport, Technical University of Denmark.

Jensen, A.V., Salling, K.B. and Leleur, S. (2013). The Sustain Appraisal Framework: Flexible Decision Support for National Sustainable Transport Planning. Paper presented at the '13th World Conference of Transport Research' Rio de Janeiro, Brazil, July 15-18.

Kahane, D., Loptson, K., Herriman, J. and Hardy, M. (2013). Stakeholder and Citizen Roles in Public Deliberation. Journal of Public Deliberation: Vol. 9, No.2, Article 2.

Koppenjan, J.F.M. and Klijn, E-H. (2004). Managing Uncertainties in Networks: A Network Approach to Problem Solving and Decision Making. Routledge.

Lami, I.M., Masala, E. and Pensa, S. (2011). Analytic Network Process (ANP) and Visualization of Spatial Data: The Use of Dynamic Maps in Territorial Transformation Processes. International Journal of the Analytic Hierarchy Process, Vol. 3, No. 2, pp. 92-106.

Leleur, S. (2012). Complex Strategic Choices: Applying Systemic Planning for Strategic Decision Making. Springer.

Lessard, D.R. and Miller, R. (2013). The Shaping of Large Engineering Projects. In: Priemus, H. and van Wee, B. (Eds.), International Handbook on Mega-Projects. Edward Elgar, pp. 34-56.

Macharis, C. and Baudry, G. (2018). The Multi Actor Multi Criteria Analysis Framework. In: Baudry, G. and Macharis, C. (Eds.), Decision-Making for Sustainable Transport and Mobility. Edward Elgar, pp. 2-27.

Macharis, C. and Bernardini, A. (2015). Reviewing the Use of Multi-Criteria Decision Analysis for the Evaluation of Transport Projects: Time for a Multi-Actor Approach. Transport Policy, Vol. 37, 177-186.

Macharis, C. and Nijkamp, P. (2011). Possible Bias in Multi-Actor Multi-Criteria Transportation Evaluation: Issues and Solutions. Research Memorandum 2011-31. Faculty of Economics and Business Administration, VU University Amsterdam.

Macharis, C. and Nijkamp, P. (2013). Multi-Actor and Multi-Criteria Analysis in Evaluating Mega-Projects. In: Priemus, H. and van Wee, B. (Eds.), International Handbook on Mega-Projects. Edward Elgar, pp. 242266.

Macharis, C. Turcksin, L. and Lebeau, K. (2012). Multi Actor Multi Criteria Analysis (MAMCA) as a Tool to support Sustainable Decisions: State of Use. Decision Support Systems, Vol. 54, pp. 610-620.

Macharis, C., De Witte, A. and Turcksin, L. (2010). The Multi-Actor Multi Criteria Analysis (MAMCA) Application in the Flemish Long-Term Decision Making Process on Mobility and Logistics. Transport Policy, Vol. 17, pp. 303-311.

Martens, K. and van Weelden, P. (2014) Decision-Making on Transport Infrastructure and Contested Information: A Critical Analysis of Three Approaches, European Planning Studies, Vol. 22, No. 3, pp. 648666. 
Mcdowall, W. and Eames, M. (2007). Towards a Sustainable Hydrogen Economy: A Multi-Criteria Sustainability Appraisal of Competing Hydrogen Futures. International Journal of Hydrogen Energy, Vol. 32, No.18, pp. 4611-4626.

Miller, L. and Lessard, D.R. (2000). Strategic Management of Large Engineering Projects: Shaping Institutions, Risks, and Governance. The MIT-Press.

Monios, J. (2017). Port Governance in the UK: Planning Without Policy. Research in Transportation Business and Management. Vol. 22, No. 1, pp. 78-88.

Morris, P.W.G. and Hough, G.H. (1987). The Anatomy of Major Projects: A Study of the Reality of Project Management. John Wiley \& Sons.

Montibeller, G. and von Winterfeldt, D. (2015). Cognitive and Motivational Biases in Decision and Risk Analysis. Risk Analysis, Vol. 35, No. 7, pp. 1230-1251.

Neale, J. (2007). The Docks Rise Again. URL: http://www.placemakingresource.com/article/768837/docksrise-again (Retrieved 18/8/2016).

Nobbe, P. (2014). The Politics of Transportation Megaprojects. Ph.D. Dissertation. Faculty of Political Science, the City University of New York, New York.

OECD (Organisation for Economic Development) (2011). Strategic Transport Infrastructure Needs to 2030, OECD Publishing.

Pensa, S., Masala, E. and Lami, I.M. (2013). Supporting Planning Processes by the Use of Dynamic Visualisation. In: Geertman, S., Toppen, F. and Stillwell, J. (Eds.), Planning Support Systems for Sustainable Urban Development. Springer, pp. 451-467.

PLA (Port of London Authority) (2014). Port of London Handbook. Compass Publications Ltd.

PLA (Port of London Authority) (2015). Port of London Handbook. Compass Publications Ltd.

PLA (Port of London Authority) (2016). Port of London Handbook. Compass Publications Ltd.

PortVision (2013). London Gateway Opens, UK's Newest Super-Port. URL: http://www.portvision.com/news--events/press-releases---news/bid/362841/London-Gateway-Opens-UK-s-Newest-Super-Port (Retrieved 12/8/2016).

Priemus, H. (2010). Decision-making on Mega-projects: Drifting on Political Discontinuity and Market Dynamics. European Journal of Transport and Infrastructure Research, Vol. 10, No. 1, pp. 19-29.

Salling, K.B. (2008). Assessment of Transport Projects: Risk Analysis and Decision Support. Ph.D. Dissertation. Department of Transport, Technical University of Denmark.

Salling, K.B., Barfod, M.B., Pryn, M.R. and Leleur, S. (2018). Flexible Decision Support for Sustainable Development: The SUSTAIN Framework Model. European Journal of Transport and Infrastructure Research, Vol. 18, No. 3, pp. 295-315.

Samset, K. (2010). Early Project Appraisal - Making the Initial Choices. Palgrave Macmillan

Samset, K. (2012). Beforehand and Long Thereafter - A Look-Back on the Concepts to Some Historical Projects. Ex Ante Academic Publisher.

Schutte, I.C. (2010). The Appraisal of Transport Infrastructure Projects in the Municipal Sphere of Government in South Africa, with Reference to the City of Tshwane. Ph.D. Dissertation. Department of Transport Economics, Logistics and Tourism. University of South Africa.

Stirling, A. (2006). Analysis, Participation and Power: Justification and Closure in Participatory Multi-Criteria Analysis. Land Use Policy, Vol. 23, No. 1, pp. 95-107.

Stirling, A. and Mayer, S. (2001). A Novel Approach to the Appraisal of Technological Risk: A Multicriteria Mapping Study of a Genetically Modified Crop. Environment and Planning C: Government and Policy, Vol. 19, No. 4, pp. 529-555.

Van Gils, M. and Klijn, E.H., (2007). Complexity in Decision Making: The Case of the Rotterdam Harbour Expansion. Connecting Decisions, Arenas and Actors in Spatial Decision Making. Planning Theory and Practice, Vol. 8, No. 2, pp. 139-159.

Ward, E.J., Dimitriou, H.T. and Dean, M. (2016a). Theory and Background of Multi-Criteria Analysis: Toward A Policy-Led Approach to Mega Transport Infrastructure Project Appraisal. Research in Transportation Economics, Special Edition, Vol. 58, pp. 21-45. 
Ward, E.J., Dimitriou, H.T. and Dean, M., (2016b). Application of Policy-Led Multi-Criteria Analysis (PLMCA) to the Appraisal of the Northern Line Extension (NLE), London. Research in Transportation Economics, Vol. 58, pp. 46-80.

Wilmsmeier, G. and Monios, J. (2013) Counterbalancing Peripherality and Concentration: An Analysis of the UK Container Port System. Maritime Policy and Management, Vol. 40, No. 2, pp. 116-132.

Yearley, S. (2001). Mapping and Interpreting Societal Responses to Genetically Modified Crops and FoodRethinking Risk: A Pilot Multi-Criteria Mapping of a Genetically Modified Crop in Agricultural Systems in the UK by Andy Stirling; Sue Mayer - Review. Social Studies of Science, Vol. 31, No. 1, pp. 151-160. 